\title{
First Record of Dicephalism in the Common Krait, Bungarus caeruleus (Schneider 1801), from Nepal
}

\author{
Kamal Devkota ${ }^{1,2}$, Amod Ghimire ${ }^{1}$, Chhabilal Thapamagar ${ }^{1,3}$, Van Wallach ${ }^{4}$, and David Wojnowski ${ }^{2,5}$ \\ ${ }^{1}$ Nepal Toxinology Association, Kawasoti, Nawalpur, Nepal (devkotakamal67@gmail.com) \\ ${ }^{2}$ Save The Snakes, 2929 35th St \#5402, Sacramento, California 95817, USA \\ ${ }^{3}$ Kaligandaki Health Foundation, Kawasoti, Nawalpur, Nepal \\ ${ }^{4} 4$ Potter Park, Cambridge, Massachusetts 02138, USA \\ ${ }^{5}$ Department of Early Childhood and Elementary Education, College of Education \& Human Development, Georgia State University, Atlanta, Georgia 30303, USA
}

$\mathrm{T}$ he presence of axial bifurcation in snakes consists mainly of dicephalic specimens and is well documented in the literature: Cunningham (1937), Jha and Gupta (1957), Mishra and Shah (1983), Smith and Perez-Higareda (1987), Hoser and Harris (1995), Swanson et al. (1997), McAllister and Wallach (2006), Wallach (1995, 2007, 2012, 2018), Beane (2009), Jandzik (2009), Albuquerque et al. (2010, 2013), Kim et al. (2013), Pezdirc et al. (2013), Wallach and Salmon (2013), Dieckmann et al. (2014), Gvozdenovic and Cavor (2015), Twombley (2015), and Caviglioli et al. (2016). Cunningham (1937) carried out the first comprehensive survey on axial bifurcation in serpents, which was a historical survey of 225 snakes exhibiting mainly two-headed conditions. Subsequently, the number of verified cases of axial bifurcation in snakes has risen to 1,987 and includes 112 genera, 217 species, and 255 species and subspecies (Wallach, unpubl. data). Of 181 reports of two-headed snakes from Asia, one is from Nepal (Mishra and Shah 1983; Wallach 2018, unpubl. data). Only 10 cases of dicephalism are presently known in the family Elapidae (6 species in 4 genera): Bungarus caeruleus,
Hemachatus haemachatus, Naja atra, N. kaouthia, N. naja, and Sinomicrurus japonicus (Wallach 2018).

Dicephalism is not a common phenomenon and rarely occurs in nature. Most reports involve snakes. The majority of dicephalic individuals are unable to survive with normal behavior in the wild (i.e., feeding and escaping predation) due to having two independent brains. Specific methods for locating dicephalic snakes in-situ have not been established; therefore, most, if not all, two-headed snakes have been found opportunistically. Herein, we report a noteworthy case of dicephalism in a Bungarus caeruleus (Schneider 1801) collected from the Kawasoti Municipality in Nepal along with detailed information on its external morphology and coloration.

The specimen was preserved one year ago in $70 \%$ ethanol. The total length (TL), snout-vent length (SVL) and cloaca to tail-tip length (CTL) were taken with a small rope and later converted into millimeters. Length of the head was measured from tip of the snout to the fusion zone. Scales were counted following previously described methods (Dowling 1951). Anomalous half-ventrals were not counted and partly

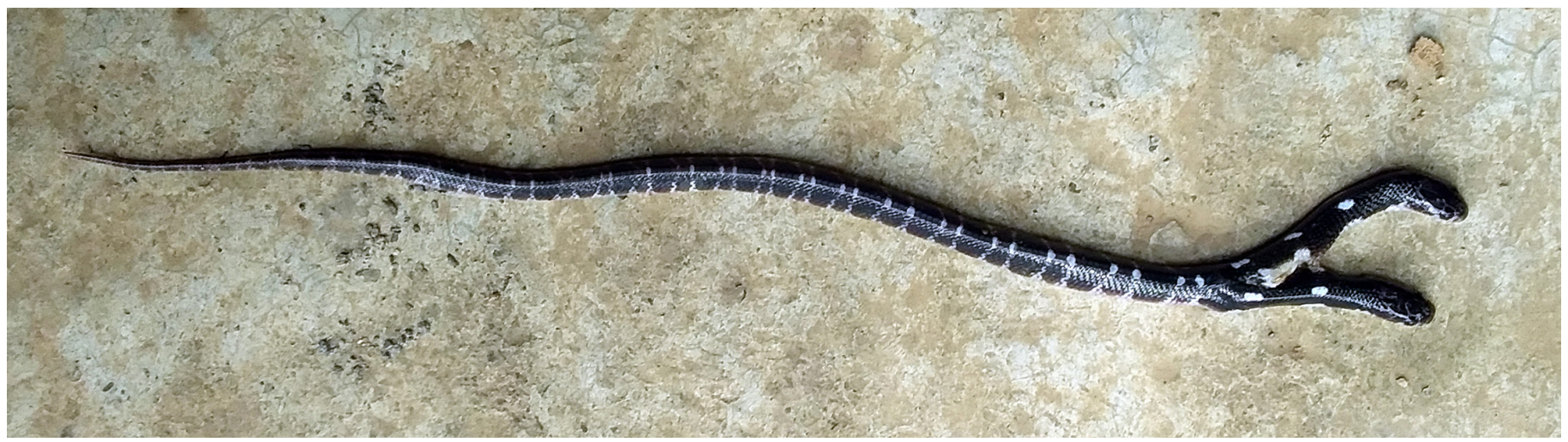

Fig. 1. Dorsal view of a dicephalic Common Krait (Bungarus caeruleus) from Kawasoti, Nepal. Photograph provided by the Kaligandaki Hospital. 
divided ventrals were counted as one scale. Paired organs were recorded as right and left. Sex of the specimen was determined by making a post-cloacal incision between the subcaudals. We dissected the preserved specimen to examine its internal anatomy but were unable to collect any pertinent data. Radiographs of the preserved dicephalic specimen were taken in the Kaligandaki Hospital with the help of the medical team.

This unusual snake was found in May 2018 on the premises of Juddha Bir Shirish Magar's home in Kawasoti Municipality, Nawalpur District, Gandaki Province, Nepal $\left(27^{\circ} 39^{\prime} 01.6^{\prime \prime} \mathrm{N}, 84^{\circ} 06^{\prime} 47.5^{\prime \prime} \mathrm{E}\right.$; elev. $\left.196 \mathrm{~m}\right)$. According to local observers, the snake was first seen alive crawling in the house. It was collected and preserved and now is deposited in the Kaligandaki Hospital, Nawalpur, Nepal (cat. no. KGH $\mathrm{BC}$ 001). The Digital Voucher Image is deposited in the Lee Kong Chain Natural History Museum, National University of Singapore (cat. no. ZRC(IMG) 2.407a,b).

The specimen is a neonatal female with the following combination of characters (Figs. 1-2): TL $=208 \mathrm{~mm}$ (from left head) and $200 \mathrm{~mm}$ (from right head); SVL $=175 \mathrm{~mm}$ (from left head) and $167 \mathrm{~mm}$ (from right head); CTL = 33 $\mathrm{mm}$; dorsal scale row formula 15:15:15; ventrals 207 (left head: $39+168$ ) and 189 (right head: $21+168$ ); cloacal scale undivided; subcaudals 52; preocular 1; postoculars 2; loreal absent; temporals $1+2$; supralabials 7 (3rd and 4th touching eye, 6th largest); and infralabials 7 . Right head and left head length from snout to fusion zone are $21 \mathrm{~mm}$ and $29 \mathrm{~mm}$ long (12\% and $16 \%$ of SVL, respectively). Scales are smooth, heads are slightly broader than necks, and eyes are small with round pupils (Fig. 2). Scales of the vertebral line are hexagonal and larger than adjacent scales. The radiographs of the dicephalic specimen (Fig. 3) revealed approximately 24 vertebrae in the right neck, 36 in the left neck, three in the fusion zone, 162 in the trunk, and 35 in the tail. The original color pattern is slightly faded and different than the color pattern of live snakes due to the duration of preservation. The dorsum is black with narrow paired white transverse bands that continue to the tip of the tail. These bands are absent in the

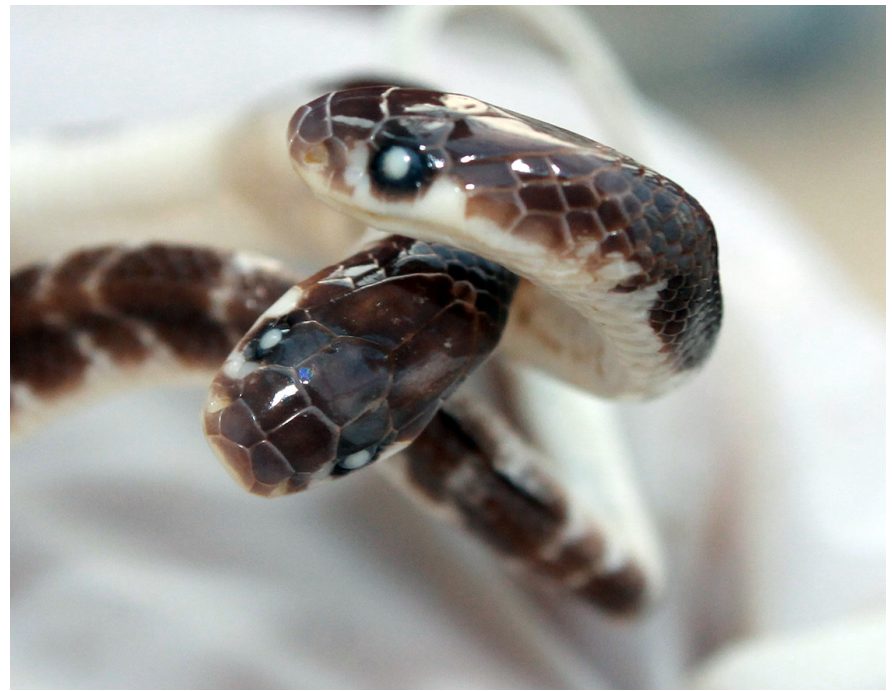

Fig. 2. Closeup view of the heads of a dicephalic Common Krait (Bungarus caeruleus) from Kawasoti, Nepal. Photograph by Kamal Devkota.

head regions and are replaced by white vertebral spots (Fig. 1 ). Both the labials and ventrals are glossy white. The tongue is pinkish-red.

Although only $9 \%$ of snakebite envenomed cases were recorded in the Western Development Region of Nepal (Magar et al. 2013), most of the people dislike, fear, and/or want to kill any snakes they encounter (Pandey et al. 2016). This snake's demise could be attributed to insufficient knowledge and lack of awareness by the local people regarding conservation; sadly, therefore, we were unable to study its behavior.

The study of dicephalic snakes is always a curiosity in the ophiological world. Two-headed snakes rarely survive long in the wild but can survive for many years in captivity, with two Pituophis catenifer living at least 21-22 years (Wallach 2007). The first record of dicephalism in Nepal was a 185 $\mathrm{mm}$ juvenile Checkered Keelback, Fowlea piscator reported by Mishra and Shah (1983) and deposited in the Natural History Museum of Nepal (Fig. 4). Jha and Gupta (1957) recorded the first dicephalic specimen of Bungarus caeruleus, a 260-mm juvenile, from Lakhaoti, Uttar Pradesh, India (Fig. 5).

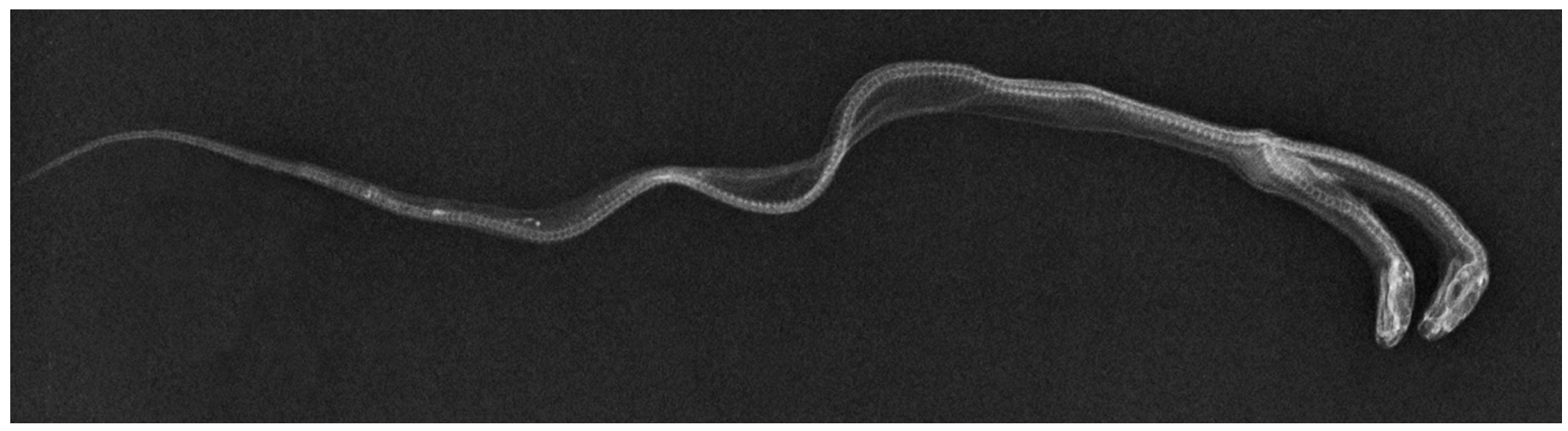

Fig. 3. Radiograph of a lateral view of a dicephalic Common Krait (Bungarus caeruleus) from Kawasoti, Nepal. Radiograph provided by the Kaligandaki Hospital. 


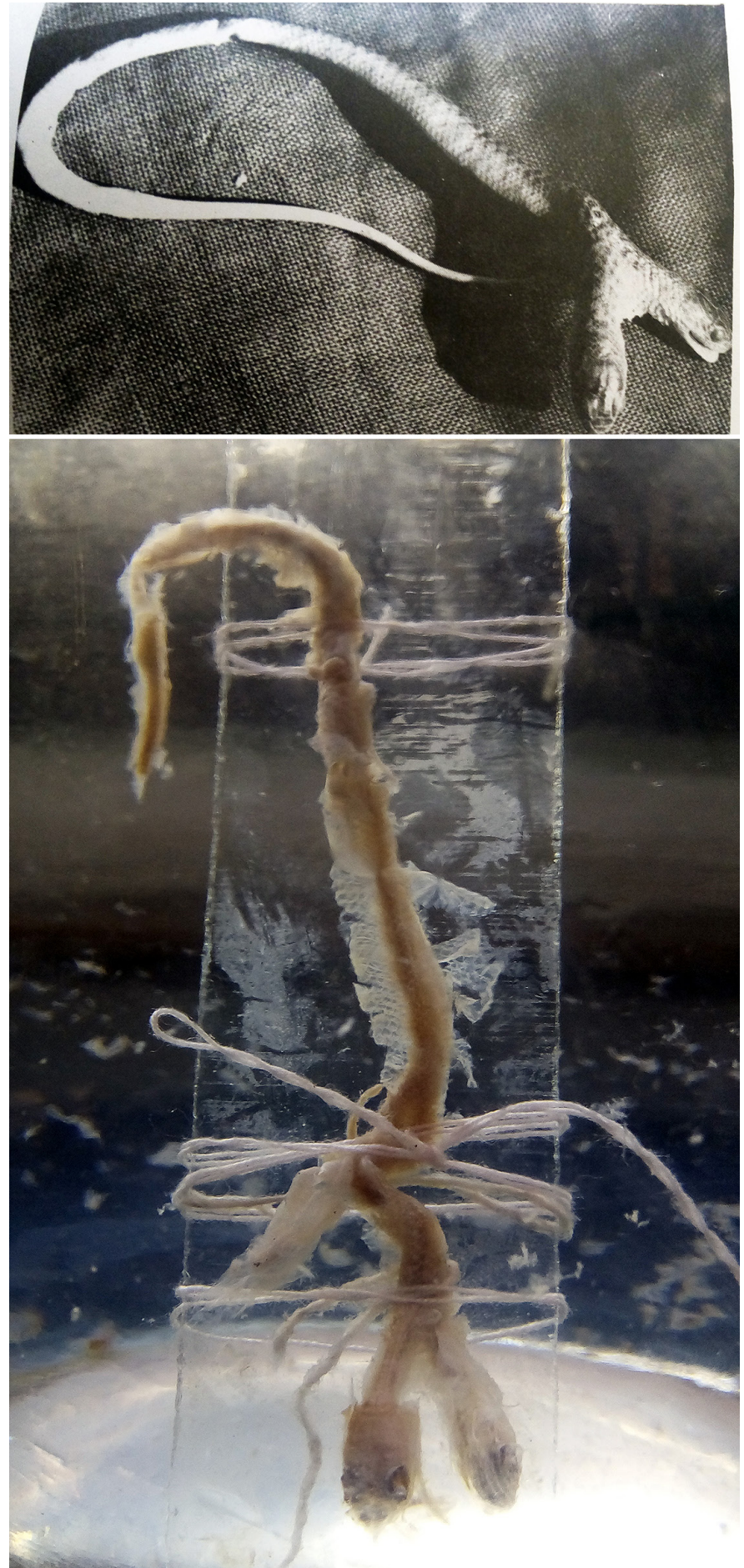

Fig. 4. First record of dicephalism in Nepal was a Checkered Keelback (Fowlea piscator) recorded by Mishra and Shah (1983) and a recent photograph of the specimen in the Natural History Museum of Nepal. Photograph by Kamal Devkota.

Our specimen is a new addition to the list of two-headed snakes and represents only the second record worldwide for $B$. caeruleus and first record from Nepal. It differs slightly from the one recorded by Jha and Gupta (1957) in regard to the degree of bifurcation. According to the classification of Smith and Perez-Higareda (1987), our specimen is clearly proar-

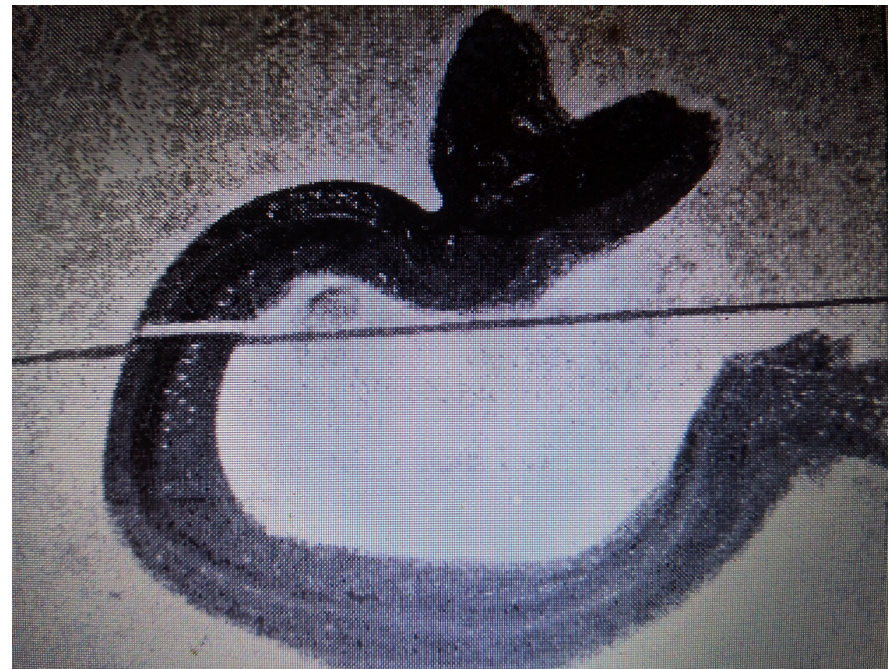

Fig. 5. First record of dicephalism in a Common Krait (Bungarus caeruleus), an Indian specimen documented by Jha and Gupta (1957).

chodichotomous, whereas the specimen described by Jha and Gupta (1957) was craniodichotomous. Jha and Gupta (1957) were unable to investigate detailed information due to the fragile condition of their specimen.

\section{Acknowledgements}

We thank Mr. Juddha Bir Shirish Magar from Kawasoti, Nawalpur, for providing the information about the specimen without which this study would not have been possible. We thank The Rufford Foundation (UK) for funding our fieldwork (Project number: $19206-1$ and $23145-2$ to the first author) while working for the "Save Snakes Save Nature" project in Nepal during which this specimen was found. We thank the Natural History Museum of Nepal for providing the literature regarding the only other previously recorded dicephalic snake from Nepal and allowing us to take photographs of the specimen. We also thank Michael G. Starkey, co-founder and executive director of "Save The Snakes," for support during this study. We are thankful to the Kaligandaki Hospital, Nawalpur, for granting us permission to carry out this study.

\section{Literature Cited}

Albuquerque, N.R. de, W.S. Arruda, A.S. Costa, R.C.V. Galharte, L.G.H. Vargas, and I.H. Moreno. 2010. A dicephalic yellow anaconda snake, Eunectes notaeus (Serpentes: Boidae), from southern Pantanal, Brazil. Journal of Natural History 44: 1989-1994

Albuquerque, N.R. de, L. Piatti, and V. Wallach. 2013. Dicephalism in the green racer snake, Philodryas patagoniensis (Serpentes, Colubridae), from southeastern Brazil. Herpetological Notes 6: 85-87.

Beane, J.C. 2009. Notes on a dicephalic eastern ribbon snake, Thamnophis sairitus sauritus. Bulletin of the Chicago Herpetological Society 44: 1-3.

Cavigiolo, L., S.A. Mella, and G. Bruni. 2016. Another case of dicephalism in Vipera aspis francisciredi (Laurenti, 1786) from northern Italy. Herpetozoa. 29: 85-86.

Cunningham, B. 1937. Axial Bifurcation in Serpents: An Historical Survey of Serpent Monsters Having Part of the Axial Skeleton Duplicated. Duke University Press, Durham, North Carolina, USA.

Dieckmann, S., G. Norval, and J.J. Mao. 2014. A description of a clutch of the Indo-Chinese rat snake, Ptyas korros (Schlegel, 1837), with notes on an 
instance of twinning. Herpetology Notes 7: 397-399.

Dowling, H.G. 1951. A proposed standard system of counting ventrals in snakes. British Journal of Herpetology 1: 97-99.

Gvozdennovic, S. and N. Cavor. 2015. First record of dicephalism in the four-lined snake Elaphe quatuorlineata Lacepede, 1789 (Serpentes: Colubridae) from Montenegro. Natura Sloveniae 17: 49-50.

Hoser, R. and P. Harris. 1995. A second case of dicephalism in Queensland carpet snakes (Morelia spilota mcdowelli) (Serpentes: Pythonidae). Herpetofauna 3: 61.

Jandzik, D. 2009. Prodichotomy in the snake Oreocryptophis porphyraceus coxi (Schulz \& Helfenberger, 1998) (Serpentes: Colubridae). Herpetological Bulletin 107: 27-29.

Jha, V.R. and P.D. Gupta. 1957. A double headed krait, Bungarus caeruleus (Schneider). Journal of the Bombay Natural History Society 54: 947-948.

Kim, I., J.K. Kim, J.J. Fong, and D. Park. 2013. Report of a dicephalic steppes ratsnake (Elaphe dione) collected in South Korea. Asian Herpetological Research 4: $182-186$.

Magar, C.L., K. Devkota, R. Gupta, R.K. Shrestha, S.K. Sharma, and D.P. Pandey. 2013. A hospital based epidemiological study of snakebite in Western Development Region, Nepal. Toxicon 69: 98-102.

McAllister, C.T. and V. Wallach. 2006. Discovery of a dicephalic western diamondback rattlesnake, Crotalus atrox (Serpents: Viperidae), from Texas, with a summary of dicephalism among members of the genus Crotalus. Journal of the Arkansas Academy of Science 60: 67-73.

Mishra, P.N. and K.B. Shah. 1983. Notes on two headed snake. Journal of Natural History Museum of Nepal 7: 101-103
Pandey, D.P., G. Subedi Pandey, K. Devkota, and M. Goode. 2016. Public perception of snakes and snakebite management: Implications for conservation and human health in southern Nepal. Journal of Ethnobiology and Ethnomedicine 12: $1-25$.

Pezdric, M., A. Zagar, and M.A. Carretero. 2013. First record of dicephalism in Vipera ammodytes (Linnaeus, 1758) from Slovenia. Herpetozoa 26: 94-95.

Smith, H.M. and G. Perez-Higareda. 1987. The literature on somatodichotomy in snakes. Bulletin of the Maryland Herpetological Society 23: 139-153.

Swanson, S., F. van Breukelen, B. Kreiser, D. Chiszar, and H.M. Smith. 1997. A double-bodied midland water snake and additions to the literature on ophidian axial bifurcation. Bulletin of the Chicago Herpetological Society 32: 80-83.

Twombley, R. 2015. A two-headed sidewinder (Crotalus cerastes) and review of axial bifurcation in snakes. Southwest Centre for Herpetological Research Bulletin 5(4): 57-60.

Wallach, V. 1995. New records of dicephalic snakes in museum collections. Herpetological Review 26: 127-129.

Wallach, V. 2007. Axial bifurcation and duplication in snakes. Part I. A synopsis of authentic and anecdotal cases. Bulletin of the Maryland Herpetological Society 43: 57-95.

Wallach, V. 2012. Two-headed snakes make high maintenance pets. Bulletin of the Chicago Herpetological Society 47: 137-139.

Wallach, V. 2018. Axial bifurcation and duplication in snakes. Part VI. A 10-year update on authentic cases. Bulletin of the Chicago Herpetological Society 53: 1-20.

Wallach, V. and G.T. Salmon. 2013. Axial bifurcation and duplication in snakes. Part V. A review of Nerodia sipedon cases with a new record from New York State. Bulletin of the Chicago Herpetological Society 48: 102-106. 